\title{
Living Quran: Resepsi Komunitas Muslim Pada Alquran (Studi Kasus di Pondok Pesantren at-Tarbiyyatul Wathoniyyah Desa Mertapada Kulon, Kec. Astatana Japura, Kab. Cirebon)

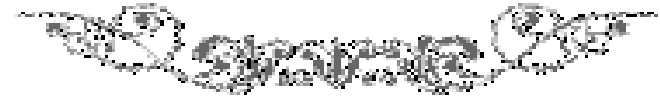 \\ Hilda Nurfuadah \\ Jurusan Ilmu Alquran dan Tafsir \\ Institut Agama Islam Negeri Syekh Nurjati Cirebon
}

\begin{abstract}
Abstrak
Artikel ini memfokuskan kajian tentang Living Quran sebagai resepsi komunitas Muslim pada Alquran. Living Quran pada hakikatnya bermula dari fenomena Quran in Everyday Life, yakni makna dan fungsi Alquran yang riil dipahami dan dialami masyarakat Muslim. Proses interaksi masyarakat terhadap Alquran tidak hanya sebatas pada pemaknaan teksnya, tetapi lebih ditekankan pada aspek penerapan (fungsional) teks-teks Alquran dalam kehidupan sehari-hari. Memfungsikan Alquran seperti ini muncul karena adanya praktik pemaknaan Alquran yang tidak mengacu pada pemahaman atas pesan tekstualnya, tetapi berlandaskan anggapan adanya "fadilah" dari bagian tertentu dalam Alquran, penerapan teks-teks Alquran tersebut kemudian menjadi tradisi yang melembaga dalam kehidupan sehari-hari masyarakat.
\end{abstract}

Kata Kunci: Living Quran, Resepsi, Fungsi, dan Komunitas.

\begin{abstract}
This article focuses on the study of the Living Quran as a reception for the Muslim community in the Koran. The Living Quran in its essence stems from the Quran phenomenon in Everyday Life, namely the meaning and function of the Koran that is truly understood and experienced by Muslim communities. The process of community interaction with the Koran is not only limited to the meaning of the text, but is emphasized more on the application (functional) aspects of the Qur'anic texts in daily life. Enabling the Qur'an as this arises because of the practice of interpreting the Koran which does not refer to the understanding of its textual messages, but based on the presumption of "fadilah" from certain parts of the Qur'an, the application of the Qur'anic texts then becomes an institutionalized tradition in people's daily lives.
\end{abstract}


Keywords: Quran Living, Reception, Function, and Community.

\section{PENDAHULUAN}

Alquran sebagai pedoman seluruh manusia merupakan firman Allah yang diyakini kesuciannya oleh para pemeluknya. Kitab Allah yang diturunkan melalui malaikat Jibril kepada Nabi Muhammad Saw inilah disampaikan kepada para sahabat sebagai dasar dalam menjalani segala aspek kehidupan mereka.

Interaksi Alquran dengan realitas akan melahirkan penafsiran yang berbeda. Perbedaan penafsiran ini bukan hanya menjadikan wacana pemikiran sesuai dengan latar belakang dan kepentingannya saja, akan tetapi dapat juga memunculkan berbagai persepsi dan tindakan praksis dalam realitas sosial.

Farid Esack mengungkapkan dalam bukunya The Introduction to the Quran, bahwa Alquran bukan hanya berfungsi sebagai pedoman, akan tetapi juga mampu memenuhi banyak fungsi dalam kehidupan Muslim. Alquran bisa berfungsi sebagai pembela kaum tertindas, penggagas perubahan, pengerem tindakan zalim, penyemangat perubahan, penenteram hati, dan bahkan obat (shifa') atau penyelamat dari malapetaka. Mereka mentransformasikan teks Alquran menjadi sebuah objek yang bernilai dengan sendirinya dan 'hidup'.

Sebuah riwayat menjelaskan bahwa Nabi Muhammad SAW pernah meruqyah dirinya sendiri dengan membaca surah mu'awwidatain yakni surah al-Falaq dan al-Nầs ketika beliau sedang sakit. ${ }^{2}$ Dari riwayat tersebut, dapat dipahami jika kemudian berkembang pemahaman masyarakat tentang fadilah atau khasiat dari ayat atau surah tertentu di dalam Alquran yang bisa digunakan sebagai obat dalam arti yang sesungguhnya, yaitu untuk menyembuhkan penyakit fisik.

Selain itu, di antara Muslim ada juga yang menjadikan ayat tertentu sebagai ayat favorit, seperti ayat fa inna ma'a al-'Usri yusran inna ma'a al'Usri yusran (Q.S. Ash-Sharh: 5-6). Baginya, ayat ini dapat memberi motivasi untuk menjadi tegar dalam menghadapi segala hal dalam kehidupan, termasuk dalam menghadapi kesulitan yang silih berganti. ${ }^{3}$ Dalam hal ini, ayat tersebut berfungsi sebagai terapi psikis secara alami.

${ }^{1}$ Farid Esack, The Introduction to the Quran (England: Oneworld, 2002), 15-17.

${ }^{2}$ Muhammad bin Ismā'ìl al-Bukhāri, Saḥịh al-Bukhārī, Juz 3, Kitab at-Ṭibb, Bab alRaqā Bi Alquran Wal Muawwidatain(Beirut: Dar al-Kutub Ilmiyyah, 1971), 26.

${ }^{3}$ Lihat tulisan Muhammad, "Mengungkap Pengalaman Muslim berinteraksi dengan Alquran" dalam Syahiron Syamsuddin (ed.), Metode Penelitian Living Quran dan Hadis (Yogyakarta: Teras, 2007), 33. 
Jiwa yang tadinya resah gelisah menjadi tenang, damai saat mendengar atau membacakan ayat tersebut dan meresapi maknanya.

Ada juga yang menjadikan surah tertentu sebagai solusi atas persoalan ekonomi. Artinya, surah tersebut digunakan sebagai alat untuk memudahkan datangnya rezeki. Seperti surah al-Wāqi'ah dalam masyarakat tertentu diyakini dapat memancing datangnya rezeki dan mendatangkan kemuliaan serta berkah bagi orang yang membacanya. ${ }^{4}$

Adapula yang menjadikan ayat Alquran sebagai pelindung dalam arti sebenarnya yaitu ayat dalam bentuk fisik tulisannya seperti yang dilakukakan 'Abdullah bin 'Umar yang menuliskan dan menggantungkan doa pada anak-anaknya yang belum balig:

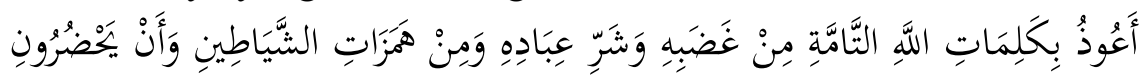

"Aku berlindung kepada kalimat-kalimat Allah yang sempurna dari kemarahan-Nya, kejahatan hamba-hamba-Nya, dan dari bisikan-bisikan syaithaan serta kedatangannya".

Keyakinan atas ayat Alquran yang bermanfaat dari bentuk fisiknya, yaitu ayat Alquran yang dituliskan dalam kertas atau benda-beda tertentu atau yang biasa disebut isim, rajah, jimat atau sebagainya, yang dipercayai sebagai penyembuh, keselamatan atau pengasihan. Salah satu ayat Alquran yang diyakini memiliki faedah adalah basmalah. $^{6}$

Persepsi semacam ini melahirkan praktik penulisan basmalah pada waktu tertentu, baik dilakukan secara pribadi oleh individu-individu di dalam masyarakat, maupun secara kolektif dilakukan oleh sekelompok masyarakat atau pondok pesantren. Pesantren adalah salah satu lembaga

${ }^{4}$ Lihat tulisan Didi Junaedi, "Penelitian Living Quran di Pesantren: Studi tentang Tradisi Pembacaan Surat al-Wāqi'ah Setiap Hari di Pondok Pesantren As-Siroj Al-Hasan Desa Kalimukti Kecamatan Pabedilan Kabupaten Cirebon” dalam Journal of Qur'an and Hadis Studies, Vol. 4, No. 2, 2015.

${ }^{5}$ Abū Dāwud Sulaimān As-Sajastanī, Sunan Abū Dāwud, juz 2, Kitab at-Tỉbb, Bab Kaifa Ruqya (Beirut: Dar al-Fikr, 2011), 231. Berikut kutipan hadisnya:

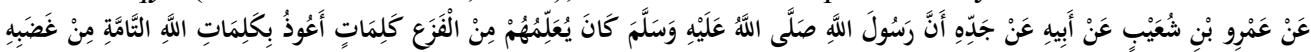

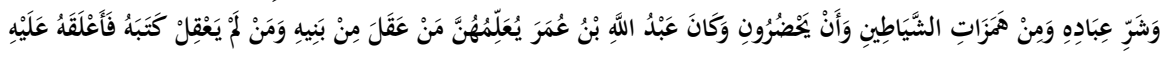

${ }^{6}$ Sayyid Qutb berpendapat, bahwa tedapat perbedaan pendapat tentang basmalah ini, apakah ia termasuk ke dalam Q.S. al-Fātiḥah ataukah satu ayat tersendiri yang digunakan dalam setiap pemulaan surah? Namun yang lebih kuat adalah satu ayat dari surat Q.S. alFātihahah. Lihat Sayyid Quṭb, Tafsir Fi Dzilalil Quran: Dibawah Naungan Alquran, terj. As'ad Yasin, Abdul Aziz Salim Basyarahil, dan Mukhothob Hamzah, juz I, (Jakarta: Gema Insani, 2000), 25. Lihat juga Muhammad Ali As-Șabuni, Rowā’ihul Bayān Tafsìr Ayāt alAḥkām Min Alquran, juz I, Bab Ahkām Ashariyah (Jakarta: Dar al-Kutub al-Islamī, 2001), 35 . 
yang lazim untuk memberlakukan ketentuan adanya praktik tersebut, kemudian diberlakukan juga pada masyarakat yang ada di dalamnya seperti Kiai, Ustaz (pengajar), santri dan elemen lain yang berada dalam lingkup Pesantren.

Salah satu Pesantren yang memberlakukan ketentuan berupa praktik penulisan basmalah setiap tanggal 1 Muharam oleh para ustaz dan santri, adalah Pesantren At-Tarbiyyatul Wathoniyyah, Desa Mertapada Kulon, Kec. Astanajapura, Kab. Cirebon, Jawa Barat.

Penuturan Kiai yang menjadi pengasuh Pesantren tersebut, praktik penulisan basmalah pada waktu, media, jumlah bilangan dan tujuan tertentu telah berlangsung secara rutin. Basmalah sebagai salah satu ayat yang diturunkan kepada Nabi --terlepas dari perbedaan penempatannya-- menjadi bahan kajian 'Ulümul Quran. Sehingga praktik tersebut --dalam ranah Studi Alquran-- bisa dikategorikan sebagai Living Quran. Living Quran yang dimaksud adalah bagaimana Alquran itu disikapi dan direspon masyarakat Muslim dalam realitas kehidupan sehari-hari menurut konteks budaya dan pergaulan sosial sebagai wujud penghormatan, penghargaan, cara memuliakan (ta'zim) kitab suci yang diharapkan pahala dan berkah sebagaimana keyakinan umat Islam terhadap Fungsi Alquran.

\section{HASIL DAN PEMBAHASAN}

\section{A. Living Quran: Sebuah Metode Kajian dalam Penelitian Alquran}

Living Quran dilihat dari segi bahasa merupakan gabungan dari dua kata yang berbeda, yaitu Living, yang berarti 'hidup' dan Quran, yaitu kitab suci umat Islam. Dengan demikian, Living Quran dapat diartikan dengan "(teks) Alquran yang hidup di masyarakat".

Istilah Living Quran bermula dari fenomena Quran Everyday Life, yakni makna Alquran yang riil dipahami dan dialami masyarakat Muslim. ${ }^{8}$ fenomena tersebut antara masyarakat Muslim satu dan yang lainnya berbeda. Jika dalam masyarakat tertentu, Alquran bisa digunakan sebagai shifa' dalam arti yang sebenarnya yaitu untuk sarana pengobatan, namun berbeda di tempat lain misalnya Alquran menjadi sebuah keindahan dengan mengagungkannya melalui dilagukan atau ditulis dalam media kaligrafi.

Syamsuddin memetakan bahwa Living Quran adalah sebuah kajian/penelitian yang objeknya adalah respon masyarakat terhadap Alquran

${ }^{7}$ Sahiron Syamsuddin, "Ranah-Ranah Penelitian dalam Studi Alquran dan Hadis", dalam Sahiron Syamsuddin (ed.), Metode Penelitian Living Quran dan Hadis (Yogyakarta: Teras, 2007), xiv.

${ }^{8}$ Sahiron Syamsuddin, "Ranah-Ranah Penelitian dalam Studi Alquran dan Hadis", 5. 
dan tafsirnya, ${ }^{9}$ yakni bagaimana Alquran itu disikapi dan direspon masyarakat Muslim dalam realitas kehidupan sehari-hari menurut konteks budaya dan pergaulan sosial dengan maksud untuk memberikan penghargaan, penghormatan, cara memuliakan (ta'zim) kitab suci yang diharapkan pahala dan berkah sebagaimana keyakinan umat Islam terhadap fungsi Alquran yang dinyatakan sendiri secara beragam. Oleh karenanya maksud yang dikandung bisa sama, tetapi ekspresi dan ekspektasi (harapan besar) masyarakat antara satu dan yang lainnya berbeda. ${ }^{10}$

Living Quran merupakan kajian tentang peristiwa sosial terkait kehadiran dan keberadaan Alquran disebuah komunitas tertentu ${ }^{11}$ dengan melihat hubungan antara Alquran dan masyarakat Islam serta bagaimana Alquran itu disikapi secara teoritik maupun dipraktikkan secara memadai dalam kehidupan sehari-hari. ${ }^{12}$ Sehingga Living Quran tidak bertumpu pada eksistensi tekstualnya, akan tetapi studi tentang fenomena sosial yang lahir terkait dengan kehadiran Alquran dalam wilayah tertentu dan mungkin pada masa tertentu.

Teori ini tidak untuk mencari kebenaran positivistik yang selalu melihat konteks, tetapi semata-mata melakukan "pembacaan" objektif terhadap fenomena keagamaan yang berkaitan langsung dengan Alquran. ${ }^{13}$

\section{B. Pemetaan Wilayah Garapan Studi Living Quran}

Hamam Faizin ${ }^{14}$ memetakan wilayah-wilayah garapan studi Living Quran yang dibagi menjadi empat bagian, yaitu:

1. Aspek oral (pembacaan) Alquran

Berupa pembacaan Alquran yang sudah menjadi tradisi dan memiliki lembaganya, seperti khataman Alquran, pembacaan Alquran dalam acara-acara tertentu, misalkan pembacaan ayat suci Alquran sebelum seminar, festival/musabaqah Alquran. Hampir di setiap negara Islam, pembacaan dalam rangka healing (pengobatan) dan seni pembacaan seperti ilmu tajwid, ilmu qiraah, murattal, tahsin dan lainnya.

\footnotetext{
${ }^{9}$ Sahiron Syamsuddin, "Ranah-Ranah Penelitian dalam Studi Alquran dan Hadis", xixiv.

${ }^{10}$ Muhammad Yusuf, "Pendekatan Sosiologi dalam penelitian Alquran”, dalam Sahiron Syamsuddin (ed.), Metode Penelitian Living Quran dan Hadis (Yogyakarta: Teras, 2007), 49-50.

${ }^{11}$ Sahiron Syamsuddin, "Ranah-Ranah Penelitian dalam Studi Alquran dan Hadis", 8.

${ }^{12}$ Muhammad Yusuf, "Pendekatan Sosiologi dalam penelitian Alquran", 39.

${ }^{13}$ Muhammad Yusuf, "Pendekatan Sosiologi dalam penelitian Alquran", 39.

${ }^{14}$ Hamam Faizin, "Alquran Sebagai Fenomena Yang Hidup: Kajian Atas Pemikiran Para Sarjana Alquran" dalam makalah International Seminar And Quranic Conference Ii, tahun 2012.
} 
2. Aspek Aural (pendegaran)

Mengimplikasi 'mendengar' Alquran yang dibaca tetapi juga memasukkan ke dalam hati.

3. Tulisan

Seperti seni kaligrafi Islam. Kaligrafi Islam sendiri merupakan persepsi estetis umat Islam dalam mengekspresikan keindahan Alquran. Selain kaligrafi, ada juga tulisan-tulisan Alquran yang dijadikan sebagai jimat dan rajah sebagai persepsi fungsi fisik Alquran oleh umat Islam.

4. Perilaku

Ketika wahyu sudah dituangkan dalam tulisan dan menjadi sebuah buku, maka ia akan menjadi sesuatu yang bernilai dengan sendirinya. Apalagi yang ditulis adalah wahyu Tuhan yang diyakini suci. Kesucian tersebut menjadikan manusia memiliki konsep tersendiri dalam memperlakukan Kitab Suci. Ia tidak boleh ditaruh di lantai, di bawah buku atau benda lainnya, tidak boleh tersentuh oleh kaki, sepatu sandal atau sesuatu yang kotor, harus dalam kondisi suci dari hadas besar maupun kecil, menghadap ke kiblat untuk membacanya, harus berkonsentrasi ketika membacanya, tidak boleh cengengesan, dan sebagainya.

\section{Resepsi Alquran}

Pada saat Alquran diturunkan, maka Rasulullah adalah sosok yang paling "bertanggung jawab" untuk menyampaikan pesan-pesan moral yang tersurat dan tersirat di dalamnya. Sebagai pembawa risalah, Rasulullah diberi otoritas penuh oleh Tuhan untuk menjelaskan pesan wahyu kepada umatnya ketika mereka mendapatkan kesulitan dalam memahami teks wahyu. Berdasarkan hal tersebut, maka Rasulullah adalah orang pertama yang meresepsi Alquran secara eksegesis-interpretatif, karena beliau merupakan sosok yang paling otoritatif dalam menginterpretasikan pesanpesan Alquran. Sekalipun demikian, betapa pun Rasulullah sangat aktif terlibat dalam penafsiran Alquran, namun tidak semua ayat Alquran ditafsirkan beliau. ${ }^{15}$

Rasulullah dalam kondisi tertentu juga meresepsi Alquran secara fungsional. Dalam konteks ini, beliau menjadikan ayat-ayat suci Alquran sebagai terapi atau yang populer dengan sebutan ruqyah. Misalnya, Rasulullah pernah membaca surat mu'awwidhatain, kemudian ditiupkan

${ }^{15}$ Muhammad Ḥusain al-Dhahabì, al-Tafsìr wa al-Mufassirūn, jilid I, (Beirut: Dar alFikr, t.th), 33 . 
pada telapak tangannya dan digosokkan pada tubuhnya pada saat beliau sakit sebelum kewafatannya. ${ }^{16}$

Fathurrosyid, membagi resepsi Alquran ke dalam 3 bagian, yaitu: 1) Resepsi eksegesis terhadap Alquran, yaitu Alquran dibaca, dipahami dan diajarkan, 2) Resepsi estetis terhadap Alquran, yaitu Alquran dituliskan sebagai kaligrafi atau tulisan dinding, baik berupa potongan ayat atau surat, dan 3) Resepsi fungsional terhadap Alquran, yaitu di mana Alquran dijadikan sebagai benda yang mempunyai kekuatan magis. Potongan ayatayat Alquran apabila dibaca secara rutin dan konsisten, baik waktu dan tempatnya, maka akan mendatangkan kekuatan, sebagai penolak bala, atau sebagai penarik rezeki dan lainnya. ${ }^{17}$

Masyarakat Muslim memiliki keyakinan bahwa kehadiran Alquran tidak saja sebagai kitab petunjuk (hudan), tetapi juga berfungsi secara fungsional yang mempunyai kekuatan mistis. Alquran sendiri memproklamirkan dirinya secara gamblang sebagai shifa' li al-Nās dan shifa' limā fí al-Sudūr. Karena itu, bukan tidak mungkin masyarakat Muslim meresepsi Alquran secara fungsional dan menjadikan amaliah, wirid dan zikir. Hal tersebut dilakukan guna mengusir roh jahat (jin), jimat untuk penglaris dagangan dan sebagainya.

Beberapa gambaran Living Quran yang keberadaannya sering kita jumpai di lingkungan Pesantren bahkan di masyarakat umum. Di antaranya adalah:

1. Alquran dibaca dan diajarkan secara rutin, bahkan menjadi bacaan wajib terutama setelah salat magrib di Pesantren. Kemudian khusus pada malam Jum'at, biasanya yang dibaca para santri dan warga Pesantren lainnya adalah surat Yāsin dan al-Wāqi'ah. ${ }^{18}$

2. Alquran dihafalkan baik secara utuh ataupun sebagian, yaitu ada yang menghafal (1 hingga 30 juz) dan ada pula yang hanya menghafal surat atau ayat tertentu sebagai bacaan salat atau acara tertentu. Biasanya Pesantren Tahfidz yang memberlakukan hafalan Alquran bagi para santrinya. ${ }^{19}$

3. Menjadikan potongan ayat, satu atau beberapa ayat tertentu dikutip dan dibentuk kaligrafi untuk dijadikan hiasan dinding atau diperlombakan.

\footnotetext{
${ }^{16}$ Muhammad bin Ismā'ìl al-Bukhārī, Saḥịh Al-Bukhārì, juz VII (Kairo: Dar alSyu'ub, t.th), 170.

${ }^{17}$ Fathurrosyid, “Tipologi Ideologi Resepsi Alquran”, dalam el-Harakah, Vol. 17, No. 2, 2015, 225-231.

${ }^{18}$ Kegiatan ini biasa dilakukan oleh Pesantren, termasuk juga biasa dilakukan di Pesantren At-Tarbiyyatul Wathoniyyah.

${ }^{19}$ Seperti yang diterapkan di Pondok Tahfidz Arjawinangun atau Baitul Quran di Tanggerang.
} 
4. Ayat Alquran dibacakan dalam acara tertentu seperti acara pernikahan, khitanan, aqiqah, Haul atau peringatan hari-hari besar Islam.

5. Ayat Alquran dilombakan dalam bentuk tilawah dan tahfidz, baik tingkat pondok, kabupaten atau kota, provinsi, nasional ataupun Internasional.

6. Ada juga yang menjadikan potongan ayat Alquran sebagai jimat yang dibawa kemana saja oleh pemiliknya sebagai perisai/tameng tolak bala atau menangkis musuh dan unsur jahat lainnya.

7. Fenomena lain adalah ayat tertentu dijadikan wirid dalam bilangan tertentu untuk memperoleh kemuliaan atau keberuntungan dengan jalan nglakoni (riyadah) meskipun terkadang terkontaminasi dengan unsur mistis dan magis.

8. Dan ada juga ayat-ayat Alquran dijadikan sebagai media pengobatan, seperti ruqyah dan penyebuhan alternatif lainnya.

Hal yang demikian merupakan bukti bahwa Alquran telah direspon oleh umat Islam dalam berbagai praktik. fenomena semacam ini memiliki daya tarik tersendiri sebagai objek kajian dan penelitian.

\section{Resepsi Fungsional Atas Alquran; Praktik Menulis Isim/Jimat}

Menurut Kamus Besar Bahasa Indonesia, isim adalah nama-nama Allah yang dijadikan sebagai mantra dan sebagainya. ${ }^{20}$ Isim yang dimaksud adalah azimat/jimat, yaitu tulisan yang dianggap mempunyai kesaktian dan dapat melindungi pemiliknya, digunakan sebagai penangkal penyakit dan sebagainya. Karena tulisan yang dibuat berasal dari Alquran yang berbentuk asma Allah sehingga disebutlah isim.

Kata jimat sendiri konon berasal dari ungkapan jawa siji dirumat yang berarti satu dipelihara lantas diakronimkan menjadi kata jimat. Manfaat yang dihasilkan dari para pengguna jimat adalah bermacam-maam bisa sebagai keselamatan, kekebalan, kewibawaan, pengasihan dan sebagainya. $^{21}$

Upaya mencari makna isim/jimat yang relatif konkrit dan tepat perlu kiranya menarik dari istilah yang jauh lebih luas dari sekadar isim/jimat. Istilah yang sering digunakan dalam hal yang berbau metafisik adalah mistik. Mistik ini merupakan istilah terluas dari isim/jimat. Secara bahasa,

\footnotetext{
${ }^{20}$ Tim Penyusun KBBI, Kamus Besar Bahasa Indonesia, Jakarta: Pusat Bahasa Departemen Pendidikan Nasional, 2008, 565.

${ }^{21}$ dikutip dari NU Online "Menahami Mistik Keseharian" dalam www.nu.or.id, diunduh pada tanggal 23 Juli 2016, pukul 23.15 WIB.
} 
mistik berasal dari bahasa Yunani, yaitu Mystikokos yang artinya rahasia (geheim) serba rahasia, tersembunyi, gelap atau terselubung dalam kekelaman. Dengan demikian, maka mistik berarti adanya sesuatu yang terselubung dan rahasia yang bersatu total dengan realitas tinggi atau dalam hal ini adalah Tuhan. ${ }^{22}$

Pengertian tersebut sangat terkait dengan fakta hidup yang hampir ada pada lini strata sosial masyarakat luas. Dalam kehidupan nyata banyak ditemukan di masyarakat sebuah kepercayaan terhadap adanya kekuatan, namun kekuatan tersebut tidak bisa dipantau secara inderawi. Termasuk kepercayaan tentang adanya kekuatan gaib pada sebuah benda tertentu. Praktik tersebut sering kali disebut dengan praktik perdukunan. Di Nusantara sendiri praktik perdukunan telah terjadi berabad-abad silam. Dukun sendiri awalnya merupakan sebutan untuk orang yang bisa menyembuhkan penyakit dengan cara memberi racikan ramuan sebagai obat serta merapalkan mantra untuk menambah khasiat obatnya atau para leluhur yang mampu membaca gejala alam dengan melihat pergerakan bintang dan planet, juga nelayan yang mampu memutuskan kapan melaut dengan melihat posisi bintang di langit. Hal demikian, menunjukkan bahwa para leluhur kita dahulu menguasai ilmu perbintangan. ${ }^{23}$

Seiring masuknya Islam di Nusantara, maka mantra-mantra, tulisan dan lainnya itu bercampur dengan Timur Tengah, ada yang berbahasa Melayu-Arab, Sunda-Arab, Jawa-Arab dan sebagainya. Hal ini juga membuktikan bahwa leluhur kita sangat lentur/fleksibel dalam memegang nilai-nilai budaya lokal. ${ }^{24}$ Maka bukan tidak mungkin jika isim atau jimat dan lainnya menggunakan tulisan arab akan tetapi dengan bahasa Jawa atau sebaliknya. Alquran sebagai kitab yang disucikan oleh umat Islam juga bukan tidak mungkin dijadikan sebagai jimat sebagai respon pengagungan dan kepercayaan bahwa ayatnya dapat menjadi penolong dan penawar (dalam artian terlepas dari makna sebenarnya ayat tersebut).

Syekh Ahmad bin al-Buni dalam kitab Shams al-Ma'arif menjelaskan tentang berbagai macam isim, rajah, wafak, ilmu-ilmu simbol, doa mantra, ilmu huruf, ilmu angka serta fungsi kegunaannya. Karya tersebut masih digunakan dan diajarkan oleh Pesantren-Pesantren tradisional di Jawa sampai saat ini. ${ }^{25}$

${ }^{22}$ Ahmad Tijani Shadiq, "Eksplorasi Jimat dalam tinjauan Antropologi" dalam www.islamnusantara.web.id diunduh pada tanggal 21 juli 2016, pukul 21.10 WIB.

${ }^{23}$ dikutip dari NU Online "Menahami Mistik Keseharian" dalam www.nu.or.id, diunduh pada tanggal 23 Juli 2016, pukul 23.15 WIB.

${ }^{24}$ dikutip dari NU Online "Menahami Mistik Keseharian" dalam www.nu.or.id, diunduh pada tanggal 23 Juli 2016, pukul 23.15 WIB.

${ }^{25}$ dikutip dari NU Online "Menahami Mistik Keseharian" dalam www.nu.or.id, diunduh pada tanggal 23 Juli 2016, pukul 23.15 WIB. 
Resepsi atas pembacaan Alquran yang memiliki fungsi lebih yakni bukan hanya sebagai teks yang dibaca atau makna yang dipraktikkan dalam kehidupan sehari-hari, akan tetapi tulisan atau bentuk fisik Alquran juga di dipahami dan diyakini memiliki kekuatan, keberkahan dan kemuliaan sehingga bukan tidak mungkin resepsi semacam ini menjadikan Alquran sebagai isim/ jimat.

\section{E. Langkah-Langkah Penelitian Living Quran}

Pada kajian ini, metode penelitian kualitatif lebih tepat dipakai untuk meneliti fenomena Living Quran. Adapun unsur-unsur yang akan dipaparkan dalam rancangan penelitian kualitatif adalah sebagai berikut. ${ }^{26}$

Pertama, menentukan lokasi, yaitu menentukan dimana lokasi yang akan dilakukan penelitian. Misalnya disebuah desa atau komunitas Muslim tertentu, kemudian memaparkan lokasi penelitian dan alasan diadakan fenomena Living Quran di tempat tersebut. Misalnya dalam judul penelitian ini: Living Quran di Pesantren: Studi Tentang Penulisan Basmalah Sebagai Isim Dipesantren Attarbiyyatul Wathoniyyah Desa Mertapada Kulon Kec. Asjap Kab. Cirebon kemudian peneliti memaparkan pula keunikan yang terdapat di tempat tersebut sehingga cocok untuk dijadikan tempat penelitian.

Kedua, menggunakan metode penelitian kualitatif, yaitu penelitian yang bertujuan untuk memahami (understanding) dunia makna yang disimbolkan dalam perilaku masyarakat menurut masyrakat itu sendiri. ${ }^{27}$ Penelitian kualitatif di dalam menjalankannya seorang peneliti dianjurkan untuk memaparkan bahwa data yang dikumpulkan berupa deskripsi, uraian detail. Penelitian kualiatatif memiliki ciri khas penyajian data menggunakan perspektif emic, yaitu data dipaparkan dalam bentuk deskripsi menurut bahasa, cara pandang dan subjek penelitian.

Ketiga, sumber data yakni subjek dari mana data diperoleh, adapun sumber data penelitian ini adalah:

a. Pimpinan Pondok Pesantren at-Tarbiyyatul Wathoniyyah.

b. Pengasuh Pondok Pesantren at-Tarbiyyatul Wathoniyyah.

c. Kiai serta Ustaz di Pondok Pesantren at-Tarbiyyatul Wathoniyyah.

d. Santri di Pondok Pesantren at-Tarbiyyatul Wathoniyyah.

e. Masyarakat sekitar Pesantren at-Tarbiyyatul Wathoniyyah.

${ }^{26}$ Abdul Mustaqim, "Metode Penelitian Living Quran: Model Penelitian Kualitatif", dalam Sahiron Syamsuddin (ed.), Metode Penelitian Living Quran dan Hadis (Yogyakarta: Teras, 2007), 65-76.

${ }^{27}$ Imam Suprayogo \& Tobroni, Metode Penelitian Sosial Agama (Bandung : Remaja Rosdakarya, 2001), 1. 
Keempat, teknik pengumpulan data, yakni mengenai data yang akan diteliti, dalam penelitian ini akan dilakukan pengumpulan data dengan 3 cara yaitu dengan:

a. Melakukan observasi terhadap kebiasaan yang terjadi dilingkungan lokasi penelitian.

b. Melakukan wawancara terhadap para responden yang telah ditentukan.

c. Melakukan dokumentasi terhadap dokumen-dokumen penting yang menunjang dalam penelitian yang dilakukan.

Kelima, unit analisis data, kriteria dan cara menetapkan jumlah reponden. Dalam penelitian ini, peneliti memiliki beberapa kategori mengenai responden yang menjadi sumber data yang dikaji dalam penelitian.

Kemudian segala bentuk informasi yang didapat pada saat melakukan observasi, wawancara dan dokumentasi, informasi-informasi tersebut dapat dikatakan sebagai data hasil penelitian. Untuk mendapatkan hasil informasi secara komperehensif, maka data-data tersebut harus melalui proses-proses analisa. Hal tersebut bertujuan untuk memperoleh gambaran yang lebih baik dari data hasil penelitian.

Adapun metode analisis data yang digunakan dalam proses tersebut adalah metode deskriptif-analitik, yaitu menggamarkan dan melukiskan keadaan subjek atau objek penelitian (bisa individu, lembaga, maupun terhadap masyarakat) berdasarkan fakta yang terlihat atau sebagaimana adanya. Kemudian menganalisa berdasarkan data-data dari hasil penelitian dan literatur yang relevan, yaitu untuk mendapatkan kesimpulan dari masalah yang akan dibahas dalam penelitian ini.

Upaya untuk memperoleh data dan kesimpulan yang valid adalah dengan uji validitas menggunakan data triangulation (triangulasi data). Oleh karenanya, dilakukan beberapa sumber data untuk mengumpulkan data yang sama.

\section{F. Hal-Hal Yang Harus Diperhatikan Oleh Peneliti Living Quran}

Dalam penelitian Living Quran, ada beberapa hal yang perlu diperhatikan oleh peneliti, yaitu sebagai berikut. ${ }^{28}$

${ }^{28}$ Didi Junaedi, "Living Quran: Sebuah Pendekatan Baru dalam Kajian Alquran (Studi Kasus di Pondok Pesantren As-Siroj Al-Hasan Desa Kalimukti Kec. Pabedilan Kab. Cirebon)" dalam Journal of Quran and Hadis Studies, Vol. 4, No. 2, 2015, 184. 
1. Penelitian Living Quran semata-mata berusaha melakukan "pembacaan" objektif terhadap fenomena keagamaan yang berkaitan langsung dengan Alquran. Penelitian Living Quran dengan menggunakan pendekatan sosiologis-fenomenologis tidak berpretensi (alasan yang dibuat-buat) untuk men-judgment fenomena yang terjadi dengan label 'benar'-'salah', 'sunnah-bid'ah', 'shar'iyyah-ghairu shar'iyyah'.

2. Living Quran tidak dimaksudkan sebagai pemahaman individu atau masyarakat dalam memahami atau menafsirkan Alquran, akan tetapi bagaimana Alquran itu direspon dan dipahami masyarakat Muslim dalam realitas kehidupan sehari-hari menurut konteks pergaulan sosial dan budaya setempat.

3. Adapun tujuan penelitian Living Quran adalah untuk menemukan makna dan nilai-nilai (meaning and values) yang melekat pada sebuah fenomena sosial keagamaan berupa praktik-praktik ritual yang berkaitan langsung dengan Alquran yang diteliti.

\section{G. Contoh Hasil Penelitian Living Quran}

Berdasarkan hasil penelitian Living Quran yang mengkaji tentang penulisan basmalah sebagai isim di Pondok Pesantren At-Tarbiyyatul Wathoniyyah Desa Mertapada Kulon, Kec. Astanajapura, Kabupaten Ciebon maka dapat diambil kesimpulan sebagai berikut.

Pertama, penulisan basmalah sebagai isim di Pesantren AtTarbiyyatul Wathoniyyah dilatarbelakangi oleh beberapa hal, yaitu sebagai berikut.

1. Landasan Teologis berasal dari Q.S. Al-Isrā': 82 dan Q.S. Fușṣilat: 44. Kemudian hadis riwayat Abū Dāwud dan beberapa riwayat hadis tentang fadilah basmalah.

2. Merujuk pada kitab Al-Nawarid al-Muntakhalah Fï Khawash AlBasmalah karya KH. Ahmad Syathori, Khazinah al-Asrär karya alUstaz as-Sayd Muhammad Haqqi al-Nāzali, Shams al-Ma'arif alKubra wa Latā'if al- 'A warif karya Imam Ahmad Ibnu 'Ali Al-Buni.

3. Argumentasi:

a. Mengikuti tradisi para ulama Nahdlatul Ulama (NU).

b. Pengijazahan dari KH. Ahmad Syathori, pendiri Pesantren AtTarbiyyatul Wathoniyyah untuk terus berlanjut kepada para santrinya melalui para penerusnya .

Kedua, proses penulisan basmalah sebagai isim di Pesantren AtTarbiyyatul Wathoniyyah merupakan kegiatan rutin yang dilaksanakan pada tanggal 1 Muharram oleh seluruh santri. Proses penulisannya dilakukan 
masing-masing, hanya cara dan praktik penulisannya yang diajarkan oleh seorang ustaz. Adapun dalam proses penulisannya ada syarat yang harus dipenuhi. Di antaranya mantapnya hati dan bertakwa, kemudian untuk alat yang digunakan adalah kertas polos, pena yang selain dari besi dan tinta za'faran (tinta merah), dan jumlah basmalah yang dituliskan sebanyak $113 \mathrm{x}$ setiap satu isim (kertas yang ditulis basmalah).

Ketiga, tujuan dari penulisan basmalah sebagai isim sebagaimana dituturkan oleh Pimpinan Pondok adalah untuk mendapatkan beberapa hal berikut ini:

1. Memperoleh ketenangan hati.

2. Terhindar dari sesuatu hal yang tidak disukai.

3. Mendapatkan kasih sayang (rahmat) dan pertolongan dari Allah Swt.

Adapun hikmah dari pengalaman penulisan basmalah yang dirasakan adalah sebagai berikut.

1. Bagi para santri, ustaz, dan para pengasuh pesantren, yaitu:

a. Memperoleh ketenangan batin.

b. Menumbuhkan rasa percaya diri.

c. Menghilangkan perasaan waswas dan rasa takut.

d. Menumbuhkan semangat hidup.

e. Memperoleh kemudahan dan kelancaran dalam beraktifitas.

2. Bagi masyarakat sekitar lingkungan pesantren:

a. Merasakan kedamaian jiwa.

b. Memperoleh pertolongan Allah.

c. Memperoleh keberkahan hidup.

Penulisan basmalah sebagai isim di Pesantren At-Tarbiyyatul Wathoniyyah merupakan respon atas dialektika masyarakat Pesantren dengan Alquran dalam penerapan resepsi fungsional terhadap Alquran.

\section{SIMPULAN}

Demikianlah pemaparan tentang Living Quran: resepsi komunitas muslim pada Alquran, dialektika antara Alquran dan realaitas mengantarkan resepsi yang beragam terhadap Alquran. Resepsi fungsional adalah salah satu yang ada dan diterapkan oleh komunitas Muslim tertentu seperti Pesantren. Pembahasan tentang resepsi lainnya dalam upaya untuk mengkaji dan memaparkan lebih luas terkait Living Quran tentu harus terus dilakukan.

\section{DAFTAR PUSTAKA}

Al-Bukhārì, Muhammad bin Ismā'ìl. Saḥịh al-Bukhārī. Beirut: Dar al-Kutub Ilmiyyah, 1971. 
t.th.

Sahịh al-Bukhārī. Kairo: Dar al-Syu'ub,

Al-Dhahabì, Muhammad Husain. al-Tafsirir wa al-Mufassirün. Beirut: Dar alFikr, t.th.

Esack, Farid. The Introduction to the Quran. England: Oneworld, 2002.

Faizin, Hamam. "Alquran Sebagai Fenomena Yang Hidup: Kajian Atas Pemikiran Para Sarjana Alquran" dalam makalah International Seminar And Quranic Conference Ii, 2002.

Fathurrosyid, "Tipologi Ideologi Resepsi Alquran”, dalam el-Harakah, Vol. 17, No. 2, 2015.

Junaedi, Didi. "Penelitian Living Quran di Pesantren: Studi tentang Tradisi Pembacaan Surat al-Wāqi'ah Setiap Hari di Pondok Pesantren AsSiroj Al-Hasan Desa Kalimukti Kecamatan Pabedilan Kabupaten Cirebon" dalam Journal of Qur'an and Hadis Studies, Vol. 4, No. 2, 2015.

Muhammad. "Mengungkap Pengalaman Muslim berinteraksi dengan Alquran" dalam Syahiron Syamsuddin (ed.), Metode Penelitian Living Quran dan Hadis. Yogyakarta: Teras, 2007.

Mustaqim, Abdul. "Metode Penelitian Living Quran: Model Penelitian Kualitatif", dalam Sahiron Syamsuddin (ed.), Metode Penelitian Living Quran dan Hadis. Yogyakarta: Teras, 2007.

NU Online. "Menahami Mistik Keseharian" dalam www.nu.or.id, diunduh pada tanggal 23 Juli 2016, pukul 23.15 WIB.

Quṭb, Sayyid. Tafsir Fi Dzilalil Quran: Dibawah Naungan Alquran. Terj. As'ad Yasin, Abdul Aziz Salim Basyarahil, dan Mukhothob Hamzah. Jakarta: Gema Insani, 2000.

Al-Ṣabunì, Muhammad Ali. Rowā'ihul Bayān Tafsìr Ayāt al-Ahkām Min Alquran. Jakarta: Dar al-Kutub al-Islami, 2001.

Al-Sajastanì, Abū Dāwud Sulaimān. Sunan Abū Dāwud. Beirut: Dar al-Fikr, 2011.

Shadiq, Ahmad Tijani. "Eksplorasi Jimat dalam tinjauan Antropologi" dalam www.islamnusantara.web.id diunduh pada tanggal 21 juli 2016, pukul 21.10 WIB.

Suprayogo, Imam \& Tobroni. Metode Penelitian Sosial Agama. Bandung: Remaja Rosdakarya, 2001.

Syamsuddin, Sahiron. "Ranah-Ranah Penelitian dalam Studi Alquran dan Hadis", dalam Sahiron Syamsuddin (ed.), Metode Penelitian Living Quran dan Hadis. Yogyakarta: Teras, 2007.

Tim Penyusun KBBI. Kamus Besar Bahasa Indonesia. Jakarta: Pusat Bahasa Departemen Pendidikan Nasional, 2008. 
Living Quran: Resepsi Komunitas Muslim Pada Alquran (Studi Kasus di Pondok Pesantren AtTarbiyyatul Wathoniyyah Desa Mertapada Kulon, Kec. Astatana Japura, Kab. Cirebon)

Yusuf, Muhammad. "Pendekatan Sosiologi dalam penelitian Alquran", dalam Sahiron Syamsuddin (ed.), Metode Penelitian Living Quran dan Hadis. Yogyakarta: Teras, 2007. 